\title{
The House of the LORD ... the house of $\operatorname{man}^{1}$ $J C P A U W^{2}$
}

\begin{abstract}
The idea of cult centralisation in ancient Israel is investigated as a form of disenchantment. The Temple in Jerusalem can now be styled The House of the LORD and the countryside ought to be bereft of holy places and holy objects. However, the LORD did not stay in his "House". Was this the start of a global process of disenchantment reaching its culmination in modernity? The question is posed whether the world could still be the enchanted house of man now that the LORD is absent. The article suggests that science associated with the Torah of nature can still discover an enchanted world.
\end{abstract}

Key words: Max Weber, disenchantment, secularisation, cult, centralisation, bronze, serpent, Calvinism, re-enchantment, science

\section{Max Weber and disenchantment}

In November 1917 Max Weber presented a lecture at a meeting of the Freistudentischen Bund: Landesverband Bayern on science as a profession. The lecture was published in 1919. It is probably the main source today of the idea of the disenchantment (Entzauberung/Onttowering) of the world in modern times. Weber maintained that, with sufficient effort, one can find out that 'there are in principle no mysterious, incalculable powers at work, but rather that one could in principle master everything through calculation. But that means the disenchantment of the world' (Weber 2004: 274). (By "calculation" he does not mean mathematical calculations only, but rather a rational and intellectual working out of steps to reach a goal.)

Here is the original (Weber 1919), to give some context:

Mächte gebe, die da hineinspielen, daß man vielmehr alle Dinge - im Prinzip durch Berechnen beherrshen könne. Das aber bedeutet: die Entzauberung der Welt. Nicht mehr, wie der Wilde, für den es solche Mächte gab, muß man zu magischen Mitteln greifen, um die Geister zu beherrschen oder zu erbitten. Sondern technische Mittel und Berechnung leisten das. Dies vor allem bedeutet die Intellektualisierung als solche.

It is very important for this piece that Weber adds that the process of disenchantment has being playing out for thousands of years. It should also be noted that he puts quotation marks around the word "progress" in the sentence following the quotation cited above. He is at best ambivalent about disenchantment. However, in 2000 the sociologist Richard Jenkins wrote:

1 Acknowledgement: Sincere thanks to Fanie de Beer, who made the publication possible; to Christiaan Pauw, Willem Boshoff, Danie Goosen and Johannes Vorster for insightful discussions; and to Martjie

2. Bosman Johannes Heidema, Kobus Wolvaardt, Chris Swanepoel and Danie Schutte. Paum is an extraordinary professor in the Department of Public Administration and Management, Unisa. E-mail: pauwjc@unisa.ac.za and kerneels@intekom.co.za

TD The Journal for Transdisciplinary Research in Southern Africa, 11(2) November 2015, Special edition: Reenchantment pp. 73-84. 
'For Weber the disenchantment of the world lay right at the heart of modernity ... it is definitive of his concept of modernity, "the key concept within Weber's account of the distinctiveness and significance of Western culture" (Schroeder 1995: 228)' (Jenkins 2000: 12). Disenchantment has two intertwined aspects according to Jenkins. 'On the one hand, there is secularization and the decline of magic; on the other hand, there is the increasing scale, scope, and power of the formal means-ends rationalities of science, bureaucracy, the law, and policy-making' (Ibid).

Weber's views must be understood in their historical context. At the beginning of the 20th century physical nature was on her best behaviour. Natural science was understood to be proof of a mechanical universe. Einstein had only recently published his article on the special theory of relativity and quantum mechanics were still to come. Modernity was strong.

In the context of means-ends rationality (if that is what Berechnung indicates) it must be remarked that if you believe in magic, it is rational for you to apply it to reach an end. Further, among believers in magic a coherent discussion on the optimal use of magic, for example on the right spell to use for a specific goal is conceivable. So what really is rational or irrational are the assumptions. 'There is, for example, rationalization of mystical contemplation, that is of an attitude which, viewed from other departments of life, is specifically irrational' (Weber 1976: 26). The question is, of course, whether choosing science as the basis of life is rational.

Weber is very clear that science is a secularising force. In the quoted lecture he says: 'Nowadays nobody can doubt in his heart of hearts that science is irreligious ...' (Weber 2004: 277). In this article I am going to argue the opposite case, but in a meandering way. We first need to visit Jerusalem in the eighth century BC.

\section{Hezekiah and the snake}

Around 700 BC king Hezekiah of Judah does a strange and radical thing - a very Protestant, even Calvinistic, thing ... a very disenchanting thing ... an impious deed. He destroys the bronze serpent that according to the story we have in Numbers 21 Moses had made centuries before. The historicity of the breaking of the snake is not the issue here (see Edelman, 2008 for a sceptic), but the theology is.

\section{In the desert the Israelite people grew impatient and spoke against God and against Moses, and said, "Why have you brought us up out of Egypt to die in the desert? ...". Then the LORD sent venomous snakes among them; they bit the people and many Israelites died. The people came to Moses and said, "We sinned when we spoke against the LORD and against you. Pray that the LORD will take the snakes away from us." So Moses prayed for the people. The LORD said to Moses, "Make a snake and put it up on a pole; anyone who is bitten can look at it and live." So Moses made a bronze snake and put it up on a pole. Then when anyone was bitten by a snake and looked at the bronze snake, he lived. (New International Version: Numbers 21.)}

Hezekiah destroys a physical thing full of spirit. He desecrates an object commissioned by the LORD connecting the people of his day with their history and their tradition. He defiles an embodiment of God's direct and miraculous intervention in the lives of their forefathers, and, I suppose, in their own lives. For it is hard to believe that Nehushtan, as it was called, did not exert healing powers in the time of Hezekiah. (Similar to the pool called Bethesda as recounted in John 5, depicting - in my reading - an impatient Jesus.) 
Hezekiah destroys an "historical monument" in the quaint language of conservation legislation. From a modern vantage point, we could say he destroys a possible or even plausible physical proof of the existence of God. He destroys a magical object in a time where physical things could still be magical by nature. Is this a turning-point in the history of civilisation? It certainly appears to lie at the cusp of a big turning-point in theology. Keeping the serpent speaks of a theology. Destroying the serpent speaks of a different theology.

The spiritual nature of physical things in those days - a turn of phrase not at odds with the ontology of the time - is illustrated by the way the King's great grandson, King Josiah, dealt with bad ritual objects in the last great official purge of religious objects before the exile. One example: 'He took the Asherah pole from the temple of the LORD to the Kidron Valley outside Jerusalem and burned it there. He ground it to powder and scattered the dust over the graves of the common people' (New International Version: 2 Kings 23). When you desecrate something, you must do it according to the nature of the thing. You must defile it permanently. The reader must please keep Asherah in mind as this goddess and her figurines are of importance for our argument later. Asherah was the senior goddess in the Canaanite pantheon.

Hezekiah's disenchanting action - which would be comparable to the Pope burning the Turin Shroud or somebody closing down the sanctuary at Lourdes - contains the seeds of secularism. I will say more about secularism and secularisation later. At this stage it must be noted that we extend the application of the concept, as it were, to much earlier times than is normal. The term was originally used for events in early modern times (Berger 1969: 106) .

The destruction of the snake could be explained in various cynical ways. The management of the snake cult may have been political opponents; perhaps they were in competition with the King's Aaronite priestly allies; perhaps he was just jealous of them because they made too much money; perhaps they had a sanctuary that was in competition with the Temple and/or the Ark of the Covenant which was closer to one of the political epicentres; or perhaps it was a tactic in countering the Assyrian threat as Moshe Weinfeld explained it (Weinfeld 1964).

The explanation provided by the author of the 2 Kings 18 at this point is quite different. $\mathrm{He}$ or she sees it as obedience. The author links it to the grand programme of cult centralisation. Hezekiah

did what was right in the eyes of the LORD, just as his father David had done. He
removed the high places, smashed the sacred stones and cut down the Asherah poles.' - a
whole lot of disenchantment going on - He broke into pieces the bronze snake Moses
had made, for up to that time the Israelites had been burning incense to it. (It was called
Nehushtan.) Hezekiah trusted in the LORD, the God of Israel. There was no one like
him among all the kings of Judah, either before him or after him. He held fast to the
LORD and did not cease to follow him; he kept the commands the LORD had given
Moses. And the LORD was with him (New International Version: 2 Kings 18.)

A few verses on, Hezekiah's historian insinuates a point of criticism that in all probability was levelled at the King at the time. He puts it in the mouth of the King of Assyria's field commander - a brilliant piece of writing! The Assyrian says that when Hezekiah destroyed sanctuaries, he destroyed sanctuaries that were used to worship the LORD: 'And if you say to me, "We are depending on the LORD our God"--isn't he the one whose high places and altars Hezekiah removed, saying to Judah and Jerusalem, "You must worship before this altar in Jerusalem"?' (See Finkelstein and Silberman 2006: 269.) Some of the sanctuaries were 
sanctuaries of The LORD; and some of them were sanctuaries where the LORD was venerated in the company of other gods - as was the case in the Temple in Jerusalem.

By the way, and to add my own insinuation - I think that the words "The LORD was with him" in the above account of Hezekiah's life means that he was, among others, successful. The historian in the second book of Kings ends the account of this king a few chapters later by referring to 'all his achievements and how he made the pool and the tunnel by which he brought water into the city' (2 Kings 20). (Max Weber knew the type.)

What I am interested in are the theological reasons that can be put forward to defend smashing the snake, irrespective of the King's real reason. A quick overview:

- There should be only one sanctuary (New International Version Leviticus 17 and New International Version Deuteronomy 12).

- The burning of incense is very special to the LORD and therefore strictly controlled (New International Version: Exodus 30: 37).

- Only the LORD may be worshiped. He cannot be venerated through physical intermediaries such as the bronze serpent, because he is radically transcendent. He is, in the words of Peter Berger, 'fundamentally immune to magical manipulation' - also a point made by Weber (Berger 1969: 117).

- Religion should be pure: it should be reduced and disciplined.

- The world does not contain real competition for the LORD because it is his creation. Spirits, demons and gods must be disregarded.

- Even if one assumes that magic is real, it is not of much theological importance - at least not for the Calvinist (see the fascinating article by Watt (2013)).

A more interesting question is this: do the theological reasons that Hezekiah might have accepted or used as an excuse still have some validity today, and do they offer any clues for reenchantment?

\section{Cult centralisation}

Hezekiah's actions can be seen, as shown above, as part of cult centralisation: the ideal of 'one centre, one altar, one Tabernacle, one place of sacrifice' (Friedman 1989: 210). The centralisation of the cult in Jerusalem probably was a long process peaking with the kings Hezekiah and Josiah. According to Deuteronomy 12 the Israelites in the time of Moses are instructed as follows:

Destroy completely all the places on the high mountains and on the hills and under every spreading tree where the nations you are dispossessing worship their gods. Break down their altars, smash their sacred stones and burn their Asherab poles in the fire; cut down the idols of their gods and wipe out their names from those places. You must not worship the LORD your God in their way. But you are to seek the place the LORD your God will choose from among all your tribes to put his Name there for his dwelling. To that place you must go; there bring your burnt offerings and sacrifices, your tithes and special gifts, what you have vowed to give, and your freewill offerings, and the firstborn of your herds and flocks. There, in the presence of the LORD your God, you and your families shall eat and shall rejoice in everything you bave put your hand to, because the LORD your God has blessed you (New International Version: Deuteronomy 12).

The families and clans of course used to eat and rejoice where they lived ... and not irreligiously at that. It is reasonable to speculate that the clan leaders also had a religious 
function - whether Levite or not. One can easily assume that these religious activities showed variation from place to place, whereas the religion of the central cult was very strictly regulated if one is to ascribe some historical reliability to the Priestly writings in the Old Testament. So, the reforms had far-reaching consequences and could have aroused people against the royal house according to Moshe Weinfeld (1964: 202). He wrote: 'a people who are heart and soul and in every aspect of their daily life bound to the sacral institutions around them (the high places and sanctuaries), are one day forcibly denied them ... [A] central sanctuary ... must by necessity deprive the worshiper of that direct and spontaneous religious experience to which he was accustomed in the local cult places spread throughout the country' (Ibid). Moving religion to the city may perhaps be described in sociological terms as differentiated religious organisation. Weinfeld's words "spontaneous religious experience" had a good ring to them when they were written in the Sixties. Whether their author had good evidence for that generalisation is an open question. They do not necessarily sound good to that object of Max Weber's attention, the Calvinist.

So, in the first place, we have a reduction of religious experience and a partial replacement of religious activities.

We also have, in the second place, a serious reduction in job opportunities for religion workers in the countryside: among them Levites and/or priests. (And if the phrase "religion workers" resonates with "sex workers", it is intentional. There are translations of the Old Testament that explicitly link the Asherah poles with sexual religiosity, or religious sexuality if you will. Let's politely call it fertility rites.) The numbers of religion workers were reduced by the sword, others (I imagine) just blended into the background, and those that were left were concentrated (that is the culinary sense of "reduce") in Jerusalem. Part of the reforms was to give job opportunities at the cult in Jerusalem to those Levites that lost their jobs. The service of Levites and priests in Jerusalem was then thoroughly reorganised (New International Version: 2 Chronicles 32). Also in the case of the great grandson, Josiah, religious purification led to human resources reorganisation. 'Josiah brought all the priests from the towns of Judah and desecrated the high places, from Geba to Beersheba, where the priests had burned incense. He broke down the shrines at the gates ... Although the priests of the high places did not serve at the altar of the LORD in Jerusalem, they ate unleavened bread with their fellow priests' (New International Version: 2 Kings 23). They were put out on pension.

Thirdly we have a reduction of religious places. It is a reduction of religious space. The Temple in theory/theology becomes the only religious space/place.

Fourthly we have a reduction of holy objects. This unfortunately includes the reduction of big trees on hills in a dry landscape. The holy objects should all be in the Sanctuary now.

It is remarkable that the holy objects of the Israelite cult, with the exception of the contents of the Ark, are exceedingly holy but totally "unmysterious". They are not enchanted in the magical sense of the word. Their composition and construction are prescribed in explicit detail down to the materials, proportions and in the case of the incense, the recipe. They are described in Exodus 25 to 28. What makes them holy is the Author of their design and composition; and also the ceremony of their consecration for which direct instructions are given. (Opposite examples are to be found in the Acts of the Apostles.) At the end of the article the reader will find a cosmological application of this idea. 
Very interestingly, Max Weber suggests a connection between the monopolisation of the cult in Jerusalem and secularisation in his book Ancient Judaism. He writes: 'Domestic slaughtering and meat dinners which hitherto .... had been considered as "sacrifices" and "sacrificial feasts" were secularized. ... The profanation of all private meals was, after the rejection of the cult of the dead, the last blow which Yahwism dealt to a possible sacred significance of the sib [one's kin]' (1952: 186). Clearly, the centralisation of the cult, the destruction of holy objects and secularisation involved giving up and losing much for those that were not of the urban elite. I will maintain the connection between cult centralisation and secularisation in what follows.

Now that we have quoted Weber, who is best known for his The Protestant Ethic and the Spirit of Capitalism (1976 (1905)), the following must be repeated in the light of my emphasis on reduction above. "If compared with the "fullness" of the Catholic universe, Protestantism appears as a radical truncation, a reduction to "essentials" at the expense of a vast wealth of religious contents. This is especially true of the Calvinist version of Protestantism ...' (Berger 1969: 111). Did you notice the word "truncation"? Hezekiah the proto-Calvinist! I have now alluded to Calvinism more than once. Calvinism is known, not only through Weber as a source of capitalism, but also as a source of modern science through the Royal Society of 17th century England. In Calvinism there is an easy coming together of faith and science. Johan Heyns once made the remark that the belief that the moon is not a god allows Americans to land a spacecraft on it.

\section{Secularisation}

The word "secularisation" is used for events in early modernity but in this article the concept is extended to much earlier times. Peter L Berger, whom I have just quoted, follows Weber quite closely in many respects. He recently called himself an unreconstructed Weberian (Berger 2011). He defines secularisation in The Sacred Canopy as 'the process by which sectors of society are removed from the domination of religious institutions and symbols' (1969: 107). In the context I would like to add: "and where people lose their ability to venerate sacred objects because these objects lose their powers due to their disenchantment".

The sectors of society in Hezekiah's time that were supposed to be removed from the domination of religious institutions were the people living in the countryside. Countryside, according to late Eighth Century policy, is now bereft of religious symbols. As far as my addendum to the definition is concerned, I should add that secularisation must have an ontological aspect; otherwise it could not be linked to disenchantment.

In discussing his definition Berger thus indicates that secularisation affects the totality of cultural life and of ideation. This includes the rise of science as an autonomous and thoroughly secular perspective on the world. So secularisation has a subjective side as well. He says: 'this means that the modern West has produced an increasing number of individuals who look at the world without the benefit of religious interpretations' (1969: 107-108). Berger maintains that the disenchantment of the world begins in the Old Testament. We have considered some of the illustrative events thereof. He adds that it is Weber's view as well (1969: 201).

I would like to add a critical remark to Berger's elaboration on his definition of secularisation. Although science may be an autonomous and apparently thoroughly secular perspective on the world, as soon as it takes on this role it becomes a religion as the sociologists (including Berger) would describe it. Thus, it becomes secular in an ambivalent way. We are told that a 
central function of religion is to protect the individual from anomy; religion makes reality ordered and understandable. I wonder how many practising scientists, for example agricultural researchers, geographers and those who model weather systems really believe that what they do every day can provide an overarching perspective on the world and protect them from normlessness. Science is much more ad hoc than what metaphysicians would think. The branches of sciences do not know enough to provide the übervision required of it by the theoreticians of modernism. One could say that the scientist who believes in science as worldview thinks religiously and not scientifically. What about the obverse: Is it possible to believe in God without being religious? We will come to that.

Before addressing the critique of and other problems with the secularisation idea, let us look at the history of the phenomenon according to Berger of The Sacred Canopy and his sources. An audacious classification of themes in the history of religion in the West renders five strands that start out as stages:

1. The old religions of Egypt and Mesopotamia are cosmological. There is only one universe in which god and man co-exist and are linked as part of one system. It can be called "cosmological monism".

2. The new departure in ancient Israel in which transcendentalisation stands central. The Old Testament tells of a God that stands outside the cosmos which is his creation which he confronts but does not permeate. This idea evolved over time. Cult centralisation is a station on the way.

3. Early Christianity involves the reintroduction of mystery, miracle and magic and the outrageous idea of the incarnated and crucified God.

4. The Reformation and the Renaissance revitalises the forces of secularisation previously constrained by Catholicism.

5. Modernity.

It is the last few decades, however, that made the idea of secularisation untenable for many including Berger himself (Swatos and Christiano, 1999.) (Also see Pérez-Agote, 2014.) Except for Europe, religious belief has not been in retreat. In 1996 Berger published a piece called 'Secularism in Retreat' which he updated in 2011 as far as I can make out. The abstract starts as follows: "The "secularization theory" of the 1950s and the 1960s that was proposed by historians and social scientists, which held that modernization necessarily leads to a decline of religion in the society and in individuals, has been proven false. Although modernization may have had some secularizing effects in some areas, it has also given rise to counter-secularization'. His argument partly rests on the observation that religious communities have survived and flourished to the degree that they have not tried to adapt themselves to the alleged requirements of a secularized world. As Berger forcefully puts it in the same piece: 'experiments with secularized religion have generally failed; religious movements with beliefs and practices dripping with "reactionary supernaturalism" (the kind utterly beyond the pale at self-respecting faculty parties) have widely succeeded'. In their aggregate they provide a massive falsification of the idea that modernisation and secularisation are cognate phenomena. Minimally, one must note that counter-secularisation is at least as important a phenomenon in the contemporary world as secularisation. However, according to Berger, contemporary elites are secularised. This brings up the question whose world it is that needs re-enchantment. One sometimes feels that certain parts of society still need disenchantment more than re-enchantment. 
I came across a book with an interesting aspect on the so-called Weber thesis that capitalism (and science) facilitates disenchantment. The title of the book by Adam Mohr, based on meticulous empirical research, is Enchanted Calvinism: Labor Migration, Afflicting Sprits and Christian Therapy in the Presbyterian Church of Ghana (Mohr 2013). The central proposition of the book is that Ghanaian Presbyterian communities, both past and present, have become more enchanted - more attuned to spiritual explanations of and remedies for suffering - as they have become integrated into capitalist modes of production. Many of them were immigrants to North America. Again, the world (be it enchanted or disenchanted) is more complicated than we would have thought: people just carry on believing in God regardless.

\section{The Temple}

We have investigated an elaborate mental structure providing ideas for interpreting the centralisation of the cult from a vantage point in the very distant future from the two royal religious reformers Hezekiah and Josiah. We must now come down from these dizzy heights of sociological speculation. It is necessary for our argument to go back to the times where our discussion started.

A few words about the Temple are necessary. According to tradition, the Temple was built by King Solomon between 1000 and 900 years BC. and destroyed by Nebuchadnezzar in 587 BC. No strong archaeological evidence for its existence has been found. Its main function could have been to house the Ark of the Covenant which was a wooden receptacle of the tables of the Law. From a design point of view one should mention the Holy of Holies or inner sanctuary which was a windowless room that was entered only once a year by the High Priest - a very austere frequency! It is described as the place where the name of the LORD dwelled. Solomon prepared that inner sanctuary within the temple to set the ark of the covenant of the LORD there. The inner sanctuary was plus minus ten metres long, ten metres wide and ten metres high. He overlaid the inside with pure gold. (New International Version: 1 Kings 6.) All this is in great contrast to the academic picture we have of the variety of local sanctuaries and households where the contact with divinity was close and warm. The Temple was variously called the House of the LORD or the House of the name of the LORD. We must face the question whether the LORD actually lived there. For those of us standing in the tradition of radical monotheism that was developed over time in ancient Israel, it is impossible.

The vision of Isaiah, who was a contemporary of and pastor to Hezekiah, paints a striking intermediate view between a resident and a transcendent deity:

I saw the Lord seated on a throne, high and exalted, and the train of his robe filled the
temple. Above him were seraphs, each with six wings: With two wings they covered
their faces, with two they covered their feet, and with two they were flying. And they
were calling to one another: "Holy, holy, holy is the LORD Almighty; the whole earth is
full of his glory. "At the sound of their voices the doorposts and thresholds shook and the
temple was filled with smoke'. (New International Version: Isaiah 6.)

Now in this ecstatic vision, which is imbued with enchantment to a very high degree, the central status of the Temple is retained. Note however, that God is not experienced as being contained by the Temple. Only his robe is inside the precincts.

In addition to the metaphysical problems of saying that God lived in the Temple, there is the problem of syncretism. Unfortunately the central sanctuary mirrored the high places in the 
sense that it was the locus of other gods and even temple prostitution as is related in the history of Josiah's purification.

The tragedy is that even if Josiah prepared a place where the LORD could live, it was laid to waste a few decades later by the Babylonians. The elite of Judah were carried off into exile. What Hezekiah and Josiah did to the high places, the Babylonians did to the House of the LORD. This is crucial to the argument of this article. The purification of religion programmes of the pious Judean kings failed. Religion organised around a cult, pure or not, is not the answer. Religion is unbelief, wrote Barth (1988: 299). In the original it reads, 'Religion ist Unglaube'; and then he adds that it is not a value judgement on religions other than Christion religion: 'It formulates the judgement of divine revelation upon all religion' (1988:30). (Please allow me an auto-ethnographical footnote on Calvinism here since we talked so much about Weber. People that do not play the Calvinist language game, rarely understand how deeply sceptical Calvinists can be of religion and religion workers in general. Calvinists reject religious intermediaries. They are not surprised at the failure of secularisation due to religiosity in our day. Calvin said that man's nature is a perpetual factory of idols [(Calvin 1960: 108]. Man likes religion.)

\section{Failure}

The centralisation of the cult failed. It failed in at least three aspects. Firstly the failure in theology: the LORD is not a resident in any building. (He is not even a resident in Heaven.) Secondly: the Temple was destroyed, and the diaspora made the later temples of less significance. Thirdly: It was impossible to root out folk religion as the archaeological evidence shows (Boshoff 2015). Although the Asherahs are largely absent in the Bible after the exile, they are very much in evidence in the current archaeology of Palestine in the form of figurines (Ibid). What is called "folk religion" is also associated with magic (Trachtenberg 1982). People do not necessarily like secularisation.

In our day, secularisation conceived as a process of the dying off of religion also failed. Is this a good sign for re-enchantment? Should we return to an enchanting religion that is built around several gods, holy places, cultic feasts such as Mandela day, magic and miracles? We should not. Religion is hardly a good thing as I have argued above, quoting Barth.

I don't believe the picture of idyllic countryside pagan innocence sometimes painted in Old Testament studies. With you, dear reader, I don't believe that the sun and the moon are gods. This fact helps us to understand the first priestly account of creation of Genesis 1 . The sun and the moon don't have names. They are merely called "lights". Some of the gods that the Israelites subjected themselves to were dreadful. Moloch, a god of the Canaanites and Phoenicians, for example, required child sacrifices. Hezekiah's son Manasseh obliged. If one is distrustful of religion you have some sympathy with the disciplinary and reductive measures of Hezekiah and Josiah; although, if you are distrustful of politicians, you are not sad that the centralisation of the cult failed.

Do we still have superstition and belief in magic in our day? Do we still have immoral gods? Do we still have syncretism between the service of the LORD and other gods? Are we still enchanted by spectacle? We do and we are. Some believe that wearing famous brands can contribute to our happiness - even if they have pumpkins on the roof. Some believe that members of the pantheon on top of Hollywood Hill are interesting and worth emulating. Some Christians believe the prosperity gospel and that global capitalism is the answer. We avidly watch the modern Olympics and various world cups and feel that very much depend on

TD, 11(2), October 2015, Special edition, pp. 73-84. 
their outcomes. Reading Chris Hedges, for example his book Empire of Illusion: the end of literacy and the triumph of spectacle of 2009 can be prophylactic in this context.

\section{The Torah of nature}

Superstition has not retreated. Neither has science. The sociologist Jenkins (2014: 17) writes: 'The world may actually be becoming somewhat more mysterious rather than less. This should not necessarily be understood as an erosion of the authority of science, but rather as a potential shift in its centre of gravity towards greater epistemological pluralism'. I disagree. The world has become more mysterious because things never dreamed of are being discovered. As said before, physical nature is not as well behaved as in Weber's time. Epigenetics in biology, outlandish forms of matter in physics and cosmic microwave background in cosmology are three of the latest examples. I was not aware that these discoveries were caused by alternative epistemologies.

I would like to conclude with a link to a point made by Moshe Weinfeld (1964: 203). He writes: "Following the centralization of the cult, the Israelite religion ceased to be a religion of the cult, it had become a religion of the book. The exteriorized cultic ceremonies performed at the high place and local sanctuary were now substituted by readings of the Book of the Torah and prayers."

Let me suggest the concept The Torah of nature as one of the ways we can fight disenchantment. The centralisation of the cult and the other religious reforms of Hezekiah and Josiah were part of the movement from cosmological monism to transcendentalism referred to above. Transcendentalism holds that God, who is not limited to the cosmos, is also its creator. It is exactly here where the ways of evaluating disenchantment part. Weber does not accept this in his heart of hearts and that is why he maintains that science is irreligious. That is the reason why he disapprovingly quotes Swammerdam's saying 'I bring you proof of divine providence in the anatomy of a louse' in his lecture to the Bavarian students (Weber 2004: 276). And at the same place:

In den exakten Naturwissenschaften aber, wo man seine [Gottes] Werke physisch greifen konnte, da hoffte man, seinen Absichten mit der Welt auf die Spur zu kommen. Und heute? Wer - außer einigen großen Kindern, wie sie sich gerade in den Naturwissenschaften finden - glaubt heute noch, daß Erkenntnisse der Astronomie oder der Biologie oder der Physik oder Chemie uns etwas über den Sinn der Welt, ja auch nur etwas darüber lehren könnten: auf welchem Weg man einem solchen »Sinn - wenn es ibn gibt - auf die Spur kommen könnte? Wenn irgend etwas, so sind sie geeignet, den Glauben daran: daß es so etwas wie einen "Sinn" der Welt gebe, in der Wurzel absterben zu lassen!

On the contrary! The world has meaning precisely because it is created. By now we know that Weber's statement to the students, ' ... but rather that one could in principle master everything through calculation' was wildly optimistic at the time. I would retort "that one could in principle be enchanted by many things through calculation".

The laws of nature as explicated by natural science are wonderful. The same applies the socalled physical constants: G, c, h and the others. Honest scientific investigation lays bare a universe that is both rational and enchanting at the same time. If you believe that the universe is a creation of the LORD it gives special meaning to the discoveries of science. In his recent book No God, no science (Theology, Cosmology, Biology) Michael Hanby (2013) works out the idea that science has a basis in metaphysics and theology. The cover of the book states that 
'the Christian doctrine of creation is actually essential of the world and that the universe itself is a fundamentally metaphysical and theological concept'.

The House of the LORD built by a man called Solomon in Jerusalem did not work - that is if it ever existed. The house of man built by the LORD is our glorious and enchanting universe. 'God saw all that he had made, and it was very good.' (New International Version: Genesis 1.)

\section{References}

Barth, K. (1988) (1977) Church Dogmatics Volume 1, Part 2 (The Doctrine of the Word of God) edited by G.W. Bromiley and T.F. Torrance. Edinburgh: T. \& T. Clark.

Berger, P.L. (1969) The Sacred Canopy. Garden City, New York: Doubleday \& Company.

Berger, P.L. (1996) "Secularism in retreat." The National Interest 46:3+. Expanded Academic ASAP. Web. 27 Sep. 2011. Document URL: http://go.galegroup.com.proxy.library.nd.edu/ps/i.do?\&id=GALE\%7CA19130142\&v $=2.1 \& u=$ nd_ref\&it $=r \& p=E A I M \& s w=w$ downloaded 31 July 2014.

Boshoff, W.S. (2015) Personal communication, June 2015.

Calvin, J. (ca1960) (ca1559) Institutes of the Christian Religion. Book 1, Chapter XI, section 8. Translated by F.L. Battles and edited by J.T. McNeill. Philadelphia: Westminster Press.

Edelman, D. (2008) Hezekiah's Alleged Cultic Centralization. Journal for the Study of The Old Testament, 32 (4): 395-434.

Finkelstein, I and Silberman N.A. (2006) Temple and Dynasty: Hezekiah, the Remaking of Judah and the Rise of the Pan-Israelite Ideology. Journal for the Study of the Old Testament, 30(3): 259-285.

Friedman, R.E. 1989 (1987) Who wrote the Bible? San Francisco: Harper.

Hanby, M. (2013) No God, No Science? Theology, Cosmology, Biology. Chichester: WileyBlackwell.

Hedges, C. (2009) Empire of Illusion: the End of Literacy and the Triumph of Spectacle. New York, NY: Nation Books.

Jenkins, R. (2000) "Disenchantment, Enchantment and Re-Enchantment: Max Weber at the Millennium” Max Weber Studies 1.1, November: 11-32.

Mohr, A. (2013) Enchanted Calvinism: Labor Migration, Afflicting Spirits, and Christian Therapy in the Presbyterian Church of Ghana. Rochester, NY: University of Rochester Press.

New International Version: 2 Kings 23. http://www.biblestudytools.com/2-kings/18.html downloaded 25 July 2014

New International Version: 2 Kings. http://www.biblestudytools.com/2-kings/23.html downloaded 30 July 2014

New International Version: Deuteronomy 12. http://www.biblestudytools.com/deuteronomy/12.html downloaded 26 July 2014 
New International Version: Genesis 1. http://www.biblestudytools.com/genesis/1.html downloaded 29 July 2015

New International Version: Isiah 6. http://www.biblestudytools.com/isiah/6.html downloaded 30 July 2014

New International Version: Leviticus 17 http://www.biblestudytools.com/leviticus/17.html downloaded 25 July 2014

New International Version: Numbers 21. http://www.biblestudytools.com/numbers/21.html downloaded 25 July 2014

Pérez-Agote, A. (2014) "The notion of secularization: Drawing the boundaries of its contemporary validity” Current Sociology, 62 (6): 886-904.

Schroeder, R. 1995 "Disenchantment and its discontents: Weberian perspectives on Science and Technology”. Sociological Review, 43: 227-250.

Swatos, W.H and Christiano, K.J. (1999) "Secularization Theory: The Course of a Concept" Sociology of Religion, 60(3): 209-228.

Taylor, C. (2007) A Secular Age. Cambridge, Massachusetts, and London, England: The Belknap Press of Harvard University Press.

Trachtenberg, J. 1982 (1939) Jewish Magic and Superstition - a study in folk religion. New York: Athenum..

Watt, J.R. (2013) “Calvin's Geneva Confronts Magic and Witchcraft: The Evidence from the Consistory" Journal of Early Modern History, 17: 215-244.

Weber, M. (1952) Ancient Judaism (translation by H.H. Gerth and D. Martindale). Glencoe, Illinois: The Free Press.

Weber, M. (2002) (1919) "Wissenschaft als Beruf" Max Weber Schriften 1894-1922 Ausgewählt und herausgegeben von Dirk Kaesler Stuttgart: Kröner (Kröners Taschenbuchausgabe; Band 233). http://www.wsp-kultur.uni-bremen.de/ downloaded 2015-04-12).

Weber, M. (2004) "The vocation of science" in the essential Weber, edited by S. Whimster London and New York: Routledge: 270-287.

Weber, M. 1976 (1905) The Protestant Ethic and the Spirit of Capitalism. Translated by T. Parsons; introduction by A. Giddens. London: George Allen \& Unwin.

Weinfeld, M. (1964) "Cult Centralization in Israel in the Light of a Neo-Babylonian Analogy" Journal of Near Eastern Studies, 23(3): 202-212. 